\title{
ВАСИЛЬ СУХОМЛИНСЬКИЙ ПРО ПЕДАГОГІЧНУ МАЙСТЕРНІСТЬ УЧИТЕЛЯ
}

У статті розглянуто можливість використання ідей та педагогічної спадщини Василя Олександровича Сухомлинського щзодо становлення педагогічної майстерності вчителя на сучасному етапі реформування освіти. Виокремлено основні чинники педагогічної майстерності, які не втратили своєі актуальності й сьогодні. Встановлено, щзо використання педагогічної спадщини В. Сухомлинського $\epsilon$ актуальним у сучасній педагогіиі.

Ключові слова: педагогічна майстерність, педагогічна культура, професіоналізм, компетентність, самоосвіта, спадщина В. Сухомлинського.

В статье рассмотрен вопрос возможности использования идей Василия Александровича Сухомлинского, касающихся формирования и повылшения педагогического мастерства учителя. Выделены основные факторы педагогического мастерства, которые не потеряли своей актуальности и сегодня. Установлено, что использование педагогического наследия В. Сухомлинского является актуальным в современной педагогике.

Ключевые слова: педагогическое мастерство, педагогическая культура, профессионализм, компетентность, самообразование, наследие В. Сухомлинского.

The development of the national education system must be based on the priorities of the quality of teaching and all-round personal development, such as pedagogical skills. Nowadays there is a growing request for a skilled teacher, competitive professional, able to educate a personality pupils. One of the major challenges of our time is pedagogical skills in the broad and narrow sense and appeal to heritage of the past.

The figure of $V$. Suhomlynskyi belongs to the past which is associated with the present. The attention is paid to the actuality of $V$. Sukhomlynskyi's ideas for elaboration of modern approaches of pedagogic professionalism development. The pedagogic heritage of V. Suhomlynskyi is a storehouse of knowledge, ideas, views of professional teacher's attitude. Basing on the ideas of the famous pedagog the professional activity of teachers is enlightened as an important criteria of forming the pedagogical culture, professionalism and pedagogical skills.

According to $V$. Sukhomlynskyi, the teacher it is a person, who independently self-improves and strives to stimulate the pupils to that, who rises the own pedagogical culture and reading competence. The analysis of scientific heritage of the great teacher allowed determine the structure of pedagogical skill that includes the following components: humanism, psychological and pedagogical, methodological and professional competence, personal qualities, individual pedagogical style, didactic mastership.

$V$. Sukhomlynskyi notices that special importance belongs to pedagogical culture, the main factor of forming and development of pedagogical culture is self-education of teachers, professionalism and pedagogical skills. Besides mastering certain knowledge and special ways of thinking it is necessary for teachers to have deep transformations of the accumulated experience, development and personal enrichment about themselves as professionals.

The outstanding pedagogue singled out ways of formation and improvement of pedagogical skill: continuous lifelong education through self-education, self-improvement and, self-development, intellectual growth and humanity. Long-term pedagogical experience gave $V$. Sukhomlynskyi to assert basis, that far not everybody can fine manage with the duties of teacher, it requires professions from the man of the large soul. The power of teacher is in his knowledge and love for children.

The findings indicate that most pedagogical ideas, generated by the great teacher back in the late twentieth century, even now have not lost their relevance and educational value and serve as a basis for educational theory and guidance for teaching practice. The thoughts and ideas of $V$. Suhomlynskyi remain relevant for the further pedagogical research.

Key words: pedagogical skills, pedagogical culture, professionalism, competence, self-education, V. Sukhomlynskyi's heritage.

$$
\begin{array}{r}
\text { Бути річкою, в якій зливаються } \\
\text { гаряче серце й холодний розум, } \\
\text { не допускати поспішних, } \\
\text { непродуманих рішень- } \\
\text { ие одна з вічних гілок } \\
\text { педагогічної майстерності. } \\
\text { В. О. Сухомлинський }
\end{array}
$$

Постановка проблеми. Сучасна школа вимагає сучасного вчителя: динамічного, комунікативного, висококомпетентного. Імідж сучасного вчителя залежить насамперед від його педагогічної майстерності. Система післядипломної педагогічної освіти є однією iз чинників формування, поглиблення та вдосконалення професійних компетенцій, задовольняючи інтереси педагогів у конкурентоспроможності та затребуваності в бурхливих освітянських змінах сьогодення. 
Іншими формами професійного зростання слугують стажування, участь у семінарах, практикумах, тренінгах, вебінарах, майстер-класах тощо [3]. Наразі актуальним залишається завдання сформувати гідного педагога, що має професійний розвиток відповідно до державної політики в галузі освіти. Яскравим прикладом розв'язання зазначеної проблеми є педагогічний досвід вітчизняного гуманіста Василя Сухомлинського, творча спадщина якого має неабияке теоретичне і практичне значення.

Аналіз наукових досліджень і публікацій. Педагогічна спадщина В. О. Сухомлинського з кожним роком привертає до себе все більшу увагу науковців - не лише вітчизняних, а й закордонних. Він був унікальним педагогом, теоретиком, практиком, директором авторської школи, що в майбутньому дало йому змогу узагальнити відомості про те, яким повинен бути вчитель. «Транслятор знань», а сьогодні - носій компетентностей; фаховий предметник, що також керується принципами саморозвитку; людина, яка організовує не лише процес пізнання, а й виховання; психолог, який вивчає задатки кожного з учнів - усе це можна знайти у спадщині Василя Олександровича. Однією із найважливіших навичок учителя, за В. Сухомлинським, $є$ прагнення педагога вчитися все життя самому і виховувати таку ж навичку у школярів [6]. Ще за життя педагога вчені (О. Губко, С. Лебедєв, С. Соловейчик) почали аналізувати його здобутки. У свій час педагогічну спадщину В. Сухомлинського досліджували М. Антонець, В. Безпалько, І. Бех, Л. Бондар, Н. Гупан, Н. Дічек, Н. Кузьміна, В. Риндак. Проблема формування образу ідеального вчителя порушувалася М. Свтухом, І. Зязюном, В. Огнев’юком, I. Підласим, В. Сластьоніним тощо. Розроблена українським практиком педагогічна система збагатила науку новаторськими ідеями й положеннями, а сьогодні заслуговує на їі нове осмислення [1].

Аналіз праць учених свідчить, що проблема формування педагогічної майстерності вчителя залишається актуальною й сьогодні. Багатогранне вивчення педагогічного феномену В. Сухомлинського вказує на грунтовність його ідей для сучасності та можливість подальших наукових пошуків. Ще більшого контрасту проблема формування та вдосконалення педагогічної майстерності вчителя набуває в умовах реформування освіти, Нової української школи, вимог державної політики в галузі освіти та забезпечення якості освіти. Ще у XVIII столітті французький літератор Жак Пеше написав фразу, яка в майбутньому стала крилатою: «Все нове - це добре забуте старе». Сьогодні вона як ніщо інше вдало підкреслює цінність ідей Василя Олександровича Сухомлинського про педагогічну майстерність.

Мета статті - розглянути в педагогічній спадщині В. Сухомлинського висвітлення ідей щодо формування педагогічної майстерності сучасного вчителя.

Виклад основного матеріалу. Образ учителя в сучасних умовах зазнає значної трансформації: НУШ, освітня реформа, запити суспільства, конкуренція - усе це потребує готовності та бажання змінюватися насамперед самому. У цьому ракурсі гуманістичні ідеї В. Сухомлинського не мають часових обмежень: вони були актуальними за його життя та залишаються актуальними й сьогодні.

Звернімося до спадщини В. Сухомлинського. Майстерність педагогічна - «...високе і таке, що постійно удосконалюється, мистецтво виховання й нав- чання, доступне для кожного педагога, який працює за покликанням і який любить дітей» [2, с. 48]. А. Луцюк зазначає, що власний досвід В. Сухомлинського є універсальним, а його праці стали справжньою скарбницею педагогічної майстерності. Особисто імпонує те, що багато творів Василя Олександровича настільки універсальні, що читати їх вдається, починаючи з будь-якої сторінки. Із захопленням читаються й авторські поради, коли розумієш їх глибину, всеосяжність та універсальність; вони розкривають суть педагогічної майстерності, демонструють труднощі і складності педагогічної професії й водночас іiі романтику та благородство [4]. Наприклад, В. Сухомлинський пише, що навчання - це «обмін духовними цінностями, взаємна віддача сердечної доброти, співчуття. Усе шкільне життя повинно бути пройняте духом гуманності» [5, с. 496]. Це - вказівки до дій, набуття компетенцій та самоствердження. У книзі «Сто порад учителеві» знаходимо: «... щоб стати справжнім вихователем, треба пройти школу сердечності... Це одна 3 найтонших речей у нашій педагогічній справі. Якщо ви наполегливо оволодіваєте нею, ви будете справжнім майстром» [7, с. 11].

Учитель має поєднувати в собі майстерність фахівця та духовність людини з великої букви. Дійсно, сучасний ринок освітніх послуг зацікавлений у якості: мало знати свій предмет - необхідно бути неординарною особистістю, здатною на «суб'єктно-суб'єктні» відносини у ставленні та подачі навчального матеріалу. Учні мають доступ до інформації, чому сприяє технічний прогрес, однак жоден гаджет не виграє в духовності із живою людиною: однолітками, батьками, вчителем. Останній поєднує в собі дві спеціальності: фахівця-предметника та педагога-вихователя. Фраза «граючись вчимося» сьогодні є актуальною не лише для початкової ланки школи, та й не лише для школи взагалі. Тренінги, інтерактивне навчання, проєктні технології тощо демонструють свої переваги у вдосконаленні педагогічної майстерності.

Ще одним важливим чинником майстерності педагога, за Василем Сухомлинським, є саморозвиток, насамперед - читання. I не лише фахової літератури. «Удосконалення педагогічної майстерності кращих учителів, - писав В. Сухомлинський, - якраз і зумовлене тим, що систематичне читання безперервно наповнює море їхніх знань» [7, с. 32]. Він рекомендував педагогам створювати власну бібліотеку і поповнювати іiї джерелами з проблем науки, виховання, психології [7, с. 118]. Сьогодні це може бути персональний сайт чи блог, власний відеоканал чи добірка наукових дописів.

А ще має бути педагогічна культура саморозвитку. В. Сухомлинський вбачав в учителеві «головного світоча інтелектуального життя школяра, бо він породжує в дитини потяг до знань, повагу до науки, культури» [5, с. 49]. На його думку, кожен рік педагогічної праці має збагачуватися новими технологіями, методами та методичними прийомами роботи, інноваціями. За роки праці це створить чималий запас задач, прикладів, збірників для творчого опрацювання та вироблення педагогічного почерку вчителя [5, с. 524]. Така робота сприяє вдосконаленню педагогічної майстерності, а доповнити ï варто творчим виявом самого вчителя і вивченням кращого досвіду інших. «Запозичення найкращого досвіду - це ... перенесення ідеї. Щоб навчатися в кращих майстрів, 
треба в чомусь переконатися» [7, с. 136].

Вчитаймося у слова В. Сухомлинського, що стали крилатими та не потребують коментарів [8]:

- «Програми в усіх школах одні й ті ж, підручники однакові, але школи різні, тому що різні вчителі. Школа - це передусім учитель»;

- «Учитель, що має 25-30-річний стаж педагогічної роботи, повинен бути бадьорим, невтомним, для нього має бути не тягарем, а задоволенням піти 3 дітьми в похід, заночувати під копицею пахучого сіна, тобто... вони (педагоги) повинні бути діяльні, повні енергії, творці нових духовних цінностей»;

- «Учитель готується до хорошого уроку все життя... Така духовна і філософська основа нашої професії й технологія нашої праці: щоб дати учням іскорку знань, вчителеві треба ввібрати ціле море світла».

Саме тому спадщина В. Сухомлинського - це не лише теоретична база, а й досвід на практичному підгрунті. Особливої уваги заслуговує справжній педагогічний бестселер «Сто порад учителеві». Це в певному розумінні кодекс педагога - не лише молодого, а й досвідченого; це основа дидактики та основа саморозвитку. Нещодавно вкотре гортала цю чудову книгу. Чомусь декілька разів перечитую і міркую над 46-ю порадою: «Удосконалення педагогічної майстерності - це передусім самоосвіта, особисті ваші зусилля, спрямовані на підвищення власної культури праці і в першу чергу культури мислення... Чим більше ви вивчаєте й спостерігаєте досвід своїх старших колег, тим необхідніші вам самоспостереження, самоаналіз, самовдосконалення, самовиховання. На основі самоспостереження, самоаналізу у вас народжуватимуться власні педагогічні ідеї... Це одна 3 дуже важливих закономірностей педагогічної праці. Вона змушує завжди думати про перспективу» [9].

Висновки. Сьогодні Україні потрібен учитель XXI століття та нова українська школа - нова за своєю суттю, а не гаслами. Учитель такої школи має бути не просто надавачем послуг, а особистістю, готовою до змін, розвитку, вдосконалення. В умовах сучасних освітянських реформ головним капіталом учителя стає його компетентність, професійна кваліфікація, педагогічна майстерність. Учитель як професіонал, крім педагогічного покликання, має прагнути до постійної самоосвіти, саморозвитку та самовдосконалення. Серед шляхів розвитку майстерності педагога, за В. Сухомлинським, основну увагу слід акцентувати на постійній творчій праці, активній життєвій позиції, потребі в самовдосконаленні, співпраці з іншими педагогами, розвитку компетентностей, духовності та гуманності.

Перспективи подалыших досліджень ідей В. Сухомлинського 3 питань формування та вдосконалення педагогічної майстерності вчителя вбачаємо в аналізі сучасних наукових думок із даної проблеми та їх порівнянні зі спадщиною великого педагога. Проведене дослідження не претендує на вичерпне вирішення всіх аспектів означеної проблеми та вказує на можливість подальшого вивчення й переосмислення ідей Василя Олександровича Сухомлинського щодо аспектів педагогічної майстерності вчителя.

\section{СПИСОК ВИКОРИСТАНОЇ ЛІТЕРАТУРИ}

1. Василь Сухомлинський: життєвий шлях та педагогічні погляди / В. В. Кузьменко [та ін.]. - Вид. 3-є, перероб. і допов. - Херсон : КВНЗ «Херсон. академ. неперерв. освіти», 2018. - 151 с.

2. Гриньова В. М. Педагогічна майстерність учителя : навчальний посібник / за ред. проф. В. М. Гриньової, С. Т. Золотухіної. - Вид. 2-е, випр. і доп. Харків : «ОВС», 2006. - 224 с.

3. Деякі питання підвищення кваліфікації педагогічних і науково-педагогічних працівників : постанова Кабінету Міністрів України ; Порядок від 21.08.2019 № 800 // Урядовий кур’єр. - 2019. - 03 вересня. - № 167 (6530).

4. Луцюк А. М. Василь Сухомлинський про педагогічну майстерність учителя : монографія / А. М. Луцюк. - Вид. 2-е, випр. та допов. - Луцьк : Вежа-Друк, 2018. - 175 с.

5. Сухомлинський В. О. Розмова з молодим директором школи / В. О. Сухомлинський // Вибрані твори : в 5 т.- К. : Радянська школа, 1977. - Т. 4. - 638 с.

6. Сухомлинський В. О. Серце віддаю дітям / В. О. Сухомлинський ; [уклад. О. Сухомлинська]. Вид. 2-е. - Харків : Акта, 2018. - 537 с.

7. Сухомлинський В. О. Сто порад учителеві / В. О. Сухомлинський. - К. : Рад. школа, 1988. - 304 с.

8. Цитати Сухомлинського про вчителя. URL: https://vseosvita.ua/library/citati-suhomlinskogo-provcitela-53491.html (дата звернення: 10.07.2019).

9. Поради вчителеві, який працює у великій школі (з книги Василя Сухомлинського «Сто порад учителеві»). URL: https://cutt.ly/NwSqmAH (дата звернення: 15.07.2019).

Дата надходження до редакиії: 12.09.2019 р. 